Journal of the Bangladesh Association of Young Researchers (JBAYR), Volume 1 Number 1, January 2011, Page 109-125

ISSN 1991-0746 (Print), ISSN 2220-119X (Online), DOI: 10.3329/jbayr.v1i1.6840

\section{AN ANALYSIS ON THE PRACTICES OF PROPHET MUHAMMAD (PBUH) IN RESOLVING CONFLICTS}

\author{
Mustafa Monjur \\ Department of Islamic Studies, University of Dhaka, \\ Dhaka-1000, Bangladesh. \\ E-mail: mustafa_monjur@hotmail.com
}

\begin{abstract}
Conflict is an inevitable phenomenon of human life. Everyone strives for the peace, which can be established only on the absence of conflict. So, naturally, the presence of various conflicts in our life cycle, from the very personal level to the greater field of international arena, and the process to avoid or resolve these have been taken as a major concern by the social thinkers. In this context, Muslim scholars also give their thoughtful suggestions on the principles and methods of conflict resolution according to the Islamic ideology that basically consists of the Quran and tradition of the prophet (pbuh). In this paper, among these two core sources of Islam, the traditions of prophet (pbuh) are described to some extent that would be helpful to provide a new look to conflict management. This paper is also an attempt to present proper evidences from the history for the settlement of disputes of the current world. With the comparison of conventional and Islamic process of conflict resolution it also can help to add suitable dimensions in this regard.
\end{abstract}

KEYWORDS: Conflict resolution, Dispute, Islam, Peace, Prophet Muhammad (pbuh).

\section{INTRODUCTION}

Islam, literally derives from the word 'Silm' (M'aluf, 1976, p.347), means peace and happiness of here and hereafter. It is the only revealed religion accepted by Allah, ${ }^{1}$ the creator of whole universe. By the revelation, the holy Quran, it guides all the acts of mankind, even from the personal deeds to the international conducts. Hence, the unavoidable conflict and consequently the notion of peace are also directed in Islam. In fact, in the very beginning of humanity in Heaven, the creation of Adam and Eve, we see the conflict between the Adam-Eve and Satan (devil). According to the Quran, Allah Himself declared their enmity. ${ }^{2}$ From then, human civilization did never go without conflicts, battles and disputes. As a result, Allah gives complete principles in resolving conflicts, which are underlying in the Quran and Hadith, traditions of prophet (pbuh) ${ }^{3}$. Prophet Muhammad (pbuh) delivered all these rules and regulations and practiced these in his own life when needed. It proves the implementing features of the theoretical presentation of Islamic rules in resolving disputes as well as the perfection of Islam as the absolute religion of Allah, the Almighty.

\section{METHODOLOGY}

This study is completely based on the published secondary data and evidences. This paper largely takes the documentation of history into account. Arguments in favor of and against any conflict are critically analyzed without changing the reality. This study does not manipulate anything from the history and make an attempt to examine the contributions of prophet (pbuh) to the civilization in resolving disputes. However, in this essay, all the dimensions of conflict are not touched intentionally because of its huge area. Only some of the incidents of conflicts that happened in the life of prophet (pbuh) and the methods how he resolved those are given attention to evaluate. Analyzing the nature and characteristics of the conflict author tries to categorize these events into various types, and eventually evaluates the method used by the prophet (pbuh) on the basis of current policy for conflict resolution. In addition, this paper may be considered as the very fewer one on this specific area and certainly provides a new motion for the researchers.

\section{CONFLICT RESOLUTION}

The word "conflict" derives from the Latin 'confligere', which means "to strike together" (Barash \& Webel, 2002, p. 26). So, literally conflict might be used as both positive and negative notion. But traditionally, it prefers to take the depressing notion as it is not possible for more than one physical object to occupy the same space without a new position for each of them. From this point of view conflict means 'a prolonged battle or collision,' 'the 
opposition of mutually exclusive impulses, desires, or tendencies,' 'a controversy, a disagreement, etc.' (Weeks, 1992, p.03). In other words, it indicates the state of being hostile, a discord of action and feeling etc. Conflict, a complex phenomenon of human interaction, also described by the various synonymous terms and words as follow: fight, battle, clash, war, disagreement, impasse, destruction, fear, dispute, debate, avoid, hate, wrongdoing etc. It is defined as an incompatibility of goals or values between two or more parties in a relationship, combined with attempts to control each other and antagonistic feelings toward each other (Fisher, 1990).

However, in spite of being perceived as a negative experience by us, conflict, usually, is neither positive nor negative in or of itself. It has the potential for either a great deal of destruction or much creativity and positive social change (Kriesberg, 1998). It may also used by the optimists in a favorable circumstances. This way of positive thinking gives a new look of conflict to human civilization. Dudley Weeks (1992), world famous American facilitators in conflict studies, wrote on this new view,

"Indeed, conflict can serve as one of the engines of personal development and social evolution, generating opportunities to learn from and adapt to the diversities and differences that are natural and healthy characteristics of our society. Conflict can bring out into the open alternative ways of thinking and behaving. It can challenge us to manage our lives in ways that utilize our differences for mutual growth and benefit" (p.07).

Conflict has many faces and occurs at a number of levels of human functioning. Because of the variations of human nature and society conflict gets its nature and shape in a great variety. In fact, conflict is the outgrowth of the variation of the human society, culture, tradition and rituals. It is a normal product of diversity in beliefs and values, differences in attitudes and perceptions that competes socio-economic and political interests among individuals, social classes, ethnic groups and states (Rashid, 2005, p.50). By analyzing the ingredients of conflict Daniel Katz, One of the early theorists on conflict, created a typology that distinguishes three main sources of conflict: economic, value, and power (Katz, 1965, pp. 356-390). On the basis of these variations we see a number of conflicts in our society as Interpersonal conflict, Role conflict, Inter-group conflict, Multi-party conflict, International conflict (Fisher, R.). Some writers divide conflicts into two types, manifest conflict, the conflict within persons or between persons and groups. It also called the social conflict that includes all the disputes related to society such as family conflict, cultural conflict, communal conflict, religious conflict etc. and another one is known as underlying conflict (Rashid, 2005, p.52).

Conflict resolution means a range of methods of eradicating sources of conflict or any reduction in the severity of a conflict or the process of resolving disputes between parties. It generally works in three phases: first prevention, second reduction of the intensity of conflict and finally to an ultimate resolution (Rashid, 2005, p.66). The term "conflict resolution" is sometimes used interchangeably with the term Conflict Management, Conflict Settlement, Dispute Resolution, Alternative Dispute Resolution (ADR), etc. With some differences, in practice, all of these terms are used synonymously to establish peace and happiness through the elimination of conflicts, debates and wars.

As conflicts are not similar in all the time and spaces for the variation of its nature, type and dimension, it is quite clear that only one method or policy is not enough to resolve or reduce the whole problem. It requires different and unique methods for different conflicts. That's why we see a number of methods have been introduced on this occasion. Conflicts can be resolved in many ways: by violence, by the issue changing over time, or by mutual agreement (Barash \& Webel, 2002, p. 26). At present, the vital methods and practices of conflict resolution that have been practiced by the peacemakers are toleration, avoidance, negotiation, mediation, arbitration, adjudication, coercion ${ }^{4}$ (Rashid, 2005, p.66), collaborative law, conciliation, litigation, diplomacy. Among these negotiation, mediation and arbitration are known as the traditional approaches on resolving disputes (Weeks, 1992, Preface p. xi).

\section{PROPHET'S ATTEMPTS ON CONFLICT RESOLUTION: AN ANALYSIS}

Muhammad (pbuh), the Prophet of Islam, is the role model and imitable personality for whole mankind. ${ }^{5}$ He founded himself as the legislator of Islamic rules and rituals by his sayings and deeds. Without his tradition, a combination of his sayings, works and consents, Islamic ideology is not attainable at all. In every aspect of human behavior and conduct, Islam regulates its own method explaining the two sources, the Quran and Hadith or tradition. So, from the point of Islam, undoubtedly, Hadith, the 
perfect explanation of the Quran, is very significant to formulate a new solution.

On the burning issues of peace and conflict, we see a number of traditions along with the verses of the Quran. Prophet Muhammad (pbuh) led his fellow peoples to the ultimate peace resolving all sorts of disagreements by his numerous speeches and actions, from which scholars have formulated the Islamic idea of peace and conflict. These traditions exist mostly in module of his sayings as he directed the 'Ummah' on various occasions. And other traditions belong to the actions and deeds of prophet (pbuh), which is generally lays down in the Books of Sirah. ${ }^{6}$ In his whole life of 63 years, Muhammad (pbuh) faced a lot of conflicts, which occupied his personal level of relationship as well as his governmental and international affairs. The contemporary condition and the advent of a new religion also created complexity in this regard. Prophet (pbuh) handled all these situations with a new process that amazed the people of his age and even of current ages. The attempts taken by him at about 1400 years ago were so scientific that Islamic thinkers take these efforts as the evidences of conflict resolution of all time. The conventional approach and current research on peace and conflict study also clarifies his greatness. We can see his initiatives for peace through out the study of peace making process and methods of present world with some required modification. Here, some of the attempts taken by the prophet (pbuh) for dispute management are mentioned and briefly evaluated on the extent of the current policy of conflict settlement.

$$
\text { i. }
$$

Probably, the first attempt of prophet (pbuh) to resolve conflict and tension that historians recorded is called 'Hilful Fudul', the alliance of Fudul (Haykal, 1976, pp.57-58), a pact of Chivalry (Lings, 1983. pp.31-32), or the League of Fuzul (Sarwar, 1961, pp. 66-67). It was an Oath to resolve chaos, disorder and conflicts from the society of Mecca. Basically, it was the consequence of 'Battle of Fijar', the Sacrilegious War. In the absence of central authority in Mecca, this battle was broken out in the fair of 'Ukaz' between the 'Quraish' and the 'Qais' tribe. It prolonged its bloody feuds by ten years, from 580 to $590 A D$, in the valley of Mecca by the revengeful temper of Arab tribes (Khan, 1980, p.16). As a result of the war the law and order of Arabia had been broken; society became unsecured to live at; a numbered of lives were lost; oppression, hijack, robbery etc. took the place of hospitality in entire territory. In this situation some kind hearted people took initiative and formed 'Hilful Fudul', a committee for peace. This oath was taken among the famous tribes of Mecca such as 'Banu Hashim', 'Banu Taym', 'Banu Asad', 'Banu Zuhra' and 'Banu Muttalib' (Husain, 1967, p.7). On the proposal of Zubair ibn Abd al-Muttalib, an uncle of Prophet (pbuh), some generous citizens of Mecca named Abbdullah ibn Zadan, prophet Muhammad (pbuh), Abu Quhafah with his son Abu Bakr took active part in the agreement. They took the promise to vindicate the rights of the weak and the oppressed against tyranny, to defend the helpless, travelers and foreigners against coercion and to prevent all sorts of disturbances of peace. Some historian claimed that the leadership was belonged to Muhammad (pbuh) in lieu of Zubair ibn Abd al-Muttalib as Muhammad Ali (1972) said, "the credit of taking the lead in the formation of this humanitarian organization was due to Muhammad and his family" (p.49). However, this debate causes no decrease to the prophet's contribution to peace any more. Historians describe quite clearly his eagerness to the pledge. Even in a tradition prophet (pbuh) himself says, "I loved the oath in which I was present at the house of ibn Zadan better than the gift of red camels and I would do it again if I were called to it" (Athir, 1965, Vol. ii, p. 41). This oath played an important role to establish peace in Arabia and history remarks that there were no more wars or iniquities took place for many years after its formation (Sarwar, 1961, p.66).

This attempt, 'Hilful Fudul', was a unique one to ascertain peace resolving a great variety of problems. To protect citizens from the cruelty of unjust war as well as to minimize the conflicts between the two rivalries it succeed undoubtedly. By this oath prophet (pbuh), being free from the war, created a third party alliance and worked as a mediator between the two hostile oppositions. Here, he used the experienced method of unity of conscious people on the issue of humanity. As a result, with their justified advice and action, Arabia got back its peaceful society after a long time.

\section{ii.}

At the age of 35, Muhammad (pbuh) resolved a bloody conflict on the occasion of rebuilding the 'Kabah', the house of God. At that time 'Kabah' was in badly need of reconstruction because of a violent flood that had shattered it. Besides this, an incident of robbery of the treasures of 'Kabah' also happened for the lack of its security system as it had no ceiling and its walls were just above the height of a man (Lings, 1983, p. 41). In this circumstance, 'Quraish' along with the other clans of Mecca decided to 
rebuild 'Kabah' and the construction works were divided equally among the clans (Guillaume, 1967, p.85). After completing the reconstruction work, there arose a dispute to reset the sacred Black Stone in place. Every tribe claimed their exclusive right to have this honour and no one was ready to sacrifice his part in this prestigious issue. Eventually, an ever long battle became supposed to break out. 'Banu Abdud Dar' brought a bowl of blood and then along with 'Banu Adi', 'Banu Kaa'b' and 'Banu Lua' $y$ ', they took a pledge to fight unto death for this honour and thrust their hands into the blood (p.86). In such crucial situation the building operation was suspended for four or five days. At last, after a long conservation Abu Umayyah ibn Mugirah proposed a solution and said, "While we are all standing here, let the very first one to pass through the gate of al-Suffah be our arbitrator in this dispute" (Haykal, 1976, p.66). This proposal was granted and the first man entered through the gate was Muhammad (pbuh). Seeing him as their arbitrator people spontaneously gave their consent with his verdict. After realizing the whole matter, Muhammad (pbuh) took a robe and placed the Black Stone on the middle of the garment. Then with his suggestion the elders of each tribe took the edge of the robe and carried that to the 'Kabah' and finally, Muhammad (pbuh) himself set the holy stone in place (p.66). Every one became pleased and the building was continued and completed.

Prophet (pbuh) played the role of an arbitrator and settled a bloodshed dispute in this event. This practice of arbitration was one of the ancient evidences of the history in resolving conflicts. Here, two aspects should be examined properly. Firstly, the selection process of the arbitrator was not scientific at all and obviously not supported by the process of modern era. But, at that time, ignorance and superstition were so influential upon the Arabs that without depending on fate they remained no way to get the solution. Besides, their culture and tradition also supported them to do the same. However, the second one, perhaps the more important matter of this event, was the decision of the arbitrator. As the arbiter Muhammad (pbuh) could declare any judgment. He might give his decision in favour of his own clan, 'Quraish'. In that case, there might be the possibility of a violent battle among the tribes. But, in the way that he judged, was the best verdict in this disputable matter. He certainly resolved a vicious communal conflict by his unselfish decision. He used the technique of sharing the common interest among the rival parties, which should be practiced in the resolution of communal conflicts of the present. iii.

Being selected as the last prophet by Allah at the age of 40, Muhammad (pbuh) started to preach the new religion Islam among the inhabitants of Mecca. Islam, the purely monotheistic creed, stood as a bitter opposition of the Meccan idolaters. The teaching of 'Tawheed', oneness of God, and guidance to righteous action of Islam threatened their year long beliefs and rituals. It also attacked directly on their leadership towards the obedience of prophet (pbuh). Besides these, going with a newly launched doctrine was not natural at all for the hot tempered Meccans. So, they stood strongly against Islam, Muhammad (pubh) and Muslims, and planned to destroy Islam at the very beginning stage. They took the policy of oppression to the new Muslims, impediment on the preaching of Islam, obstruction on prophet's movement by calling him mad, magician and poet, offering a vast of wealth, honour, beautiful women, leadership and power to restrain him from the propagation, warning his guardians and clans to hold him down from his mission and not to help him etc. (Ali, 1972). But all of their constant efforts had gone in vain as Muhammad (pbuh) never accepted any sort of compromise. As a result, the number of Muslims began to increase day by day; 'Umar' and 'Hamja', the two great soldiers, accepted Islam and strengthened the power of Muslims; Abu Talib, the respected leader of Quraish and uncle and guardian of prophet (pbuh), refused neither to desist Muhammad from his mission nor to give up him without any protection (Haykal, 1976).

Having met with nothing but disappointment on all sides, the 'Quraish' decided to boycott Muhammd (pbuh), his followers and 'Banu Hashim' and 'Banu Muttalib' for their assistance to the Muslims. This ban took place between two parties, on one side 'Banu Hashim' and 'Banu Muttalib', and on the other side rest of the tribes of 'Quraish'. Intermarriage, commercial relations and any kind of transactions were totally forbidden between these two parties (Khan, 1980). In the seventh year of the prophethood this agreement was drawn up on two conditions, either to hand over Muhammad to them or to renounce their guarantee of protection of the prophet (Khan, 1980). Without taking any of these two, 'Banu Hashim' and 'Banu Muttalib' were compelled to betake themselves in a narrow valley of Mecca, named 'Shi'b Abu Talib' (Ali, 1972, p.82). As the boycott was strictly observed by the 'Quraish', the banned party had nothing to do. All the supplies to the valley were cut off. The plight of children was particularly pitiable. Sometimes they ate leaves of wild plants (Khan, 1983, p.90). However, this period of acute sufferings lasted for three years. In the tenth 
year of prophethood when Hisham ibn Amr, Zubair, Hakim ibn Khuwailid and some other sympathetic men took the initiatives to lift the intervention and to take them back to Mecca (Husain, 1967, p.14).

This event is not an example of direct conflict. Here, the action of Muhammad (pbuh) and his followers were just exposing their own belief and doing their duties of the new religion. Yet, it differentiated between the believers and non believers, which influenced the idolaters not to tolerate such deeds. In this circumstance according to the Arab tradition, a civil war was a must among the clans as they set earlier example to fight just for a horse (Guillaume, 1967). But realizing that fact, prophet (pbuh) did not take any action against the Meccans but firmly stood behind his ideology. His sacrifice, patience, tolerance and avoidance to their aggression made the situation easier to control without any massacre. In fact, it was a religious conflict that was solved by the process of tolerance and avoidance. After about ten years the effectiveness of this process was disclosed when the entire Arabia gone under the reign of the prophet (pbuh) and they took him cordially as their political as well as their religious leader.

\section{iv.}

Before prophet's 'Hijrah', Medina had no central authority like other towns of Arabia. Tribes and clans were ruled by the will of their own leader. Besides the Jewish colony, primarily Medina was divided into two famous clans, 'Aws' and 'Khazraj'. A long standing enmity divided these two parties. And the great exposer of their enmity and violence was probably the fourth and last battle between them, named the battle of 'Bua ' $h$ ', which took place just before the 'Hijrah' of prophet (pbuh). In this war both clans gave full vent to achieve victory over their enemy by any means. 'Khazraj' won at first and then the 'Aws' came back and fought so furiously that the 'Khazraj' lost heavily (Sarwar, 1961, p.166). But as no clan was ready to go down, the battle remained and a great many of both parties were killed. In this critical moment, there arose an idea of mutual agreement between the two to resolve the conflict. Martin Lings (1983) wrote,

"The dangerously prolonged state of chronic bitterness fraught with an increasing number of incidents of violence had won over many of the more moderate men of both sides to the opinion that they needed an overall chief who would unite them as Qusayy had united
Quraysh, and that there was no other solution to their problem." (p.108)

In this regard Abdullah ibn Ubay, a leading personality of 'Khazraj', was proposed as the king of Medina, but without any unanimous decision, this proposal was postponed and they were looking for another better personality who was not belonged to any of the two rival clans. Meanwhile, in the last part of eleventh year of prophethood six persons of Medina went to pilgrimage at Mecca and received the teaching of Islam. Hearing the divine call and the teachings of Muhammad (pbuh), they proposed before the inhabitant of Medina to accept Islam and eventually took Muhammad (pbuh) as their supreme leader to resolve the problem. As a result, in the next two years they sent twelve and seventy two persons from Medina respectively to meet prophet (pbuh) (Khan, 1983). They met him, accepted Islam and took two pledges in every year on the teachings of Islam. These pledges are known as 'the pledges of al-Aqaba'. ${ }^{8}$ They also invited him to go to Medina and assured to defend him at any cost. Zafrulla Khan (1980) describes their emotion and intentions as follow-

"When parting from the Holy Prophet, they submitted that they have been much weakened by internecine conflicts and there were great differences among them, but on return home they would convey the message of Islam to their brethren, and it might be that Allah, the Exalted, may bring them all together through him; in which case, they would all combine in helping him." (p.68)

At that period, Mecca was not safe for the Muslims for the oppression and conspiracy of the idolaters. Even Meccan planned a plot to kill Muhammad (pbuh) to stop the motion of Islam. In this circumstances prophet (pbuh) with the permission of Allah, decided to take the invitation fo Medinites to go to Medina for better future and on Monday 27 September, A.D. 622 he reached there (Lings, 1983, p.123). The citizen of Medina warmly welcomed him and almost all of the pagans of both 'al-Aws' and 'alKhazraj' accepted Islam spontaneously. Muhammad (pbuh) tied them with the brotherhood of Islam and the existing enmity vanished and never back again.

The conflict between 'Aws' and 'Khazraj' was a communal dispute. It was based on the honour and superiority of their own tribe, not on a common interest to achieve. Everyone claimed their supremacy over others and did 
not hesitate to hurt others in favour of his own clans. In such case, prophet (pbuh) practiced a general role of conflict resolution. He mediated between them not by the tribal customs, but by a common issue that was Islam. He centralized their thoughts from their own tribe to the teachings of Islam. He gave the similar honour and treatment to the rival parties and made them understood the significance of Islam in here and hereafter. Besides this, he launched the notion of Islamic brotherhood so that they began to think every Muslim as their brother irrespective the color, caste and clans. This remarkable policy also played a vital role to dissolve their hostility. So, it may declare that in the role of a mediator Muhammad (pbuh) was a successful leader undoubtedly.

After 'Hijrah', prophet (pbuh) had to perform some noteworthy acts to establish a safe and secured state in Medina, among which 'Medina Charter' was his one of the greatest works. Jews, a considerable power of the city, were divided into three major clans: 'Banu Qainuka', 'Banu Nadir' and 'Banu Quraizah' (Ali, 1972, p.104). 'Banu Nadir' and 'Banu Quraizah' were the allies of 'Aws' and 'Khazraj' respectively and hence they took active part in the internecine warfare of Medina. Muhammad (pbuh) tried to create a commonwealth uniting these groups and called everyone together for mutual adjustment and co-operation whereby risk of dissension might be obviated and the security of Medina might be provided for (Khan, 1980, p. 88). In this context, prophet (pbuh) consulting with the representatives of each parties, litigated a charter for the city state of Medina, a formal constitution and a covenant for its citizens. Historians considered this agreement as the first written charter the world history has ever been (Sarwar, 1961). We may summarize the theme of the charter as below-

"Muslims and Jews should live as one people; each party should keep to its own faith, and neither should interfere with that of the other; in the event of war with a third party, each should come to the assistance of the other, provided the latter were the party aggrieved and not the aggressors; in the event of an attack on Medina, both should join hands to defend it; peace should be made only after consultation with each other; Madina should be regarded as sacred by both, all bloodshed being forbidden therein; the prophet should be the final court of appeal of dispute." (Ali, 1972, p. 104)

However, prophet (pbuh) treated both group, Muslims and Jews, equally in all aspects. It gave similar status in social position, rights and responsibilities as well as in religious freedom to all inhabitants of Medina. Having equal rights and status the Jews had nothing but to co-operate with the Muslims to establish peace everywhere in Medina.

This charter proves Muhammad's (pbuh) statesmanship clearly. Haykal (1976) says,

"The politically greater achievement of Muhammad was his realization of a unity for the city of Yathrib as a whole, his construction of a political structure in which the Jews entered freely into an alliance of mutual cooperation with the Muslims" (p.179).

This was a combined process to resolve and to prevent the upcoming conflicts. As Jews were a mentionable figure at Medina and were very much capable to create domestic hazards, they must had to be well treated. But getting all the power of authority, prophet (pbuh) not only treated them well but also gave them the equal rights and status. Because he knew that discrimination creates disputes, and hence he was not ready to give any chance of it under his leadership in Medina. This diplomatic foresight indirectly compelled the Jews to obey his role. On the other hand, by the formulation of the agreement, he litigated the matter under the supreme court of justice. As both of the parties were equal before law no one had the right to break the law and order of Medina state. Lings wrote (1983)-

"In case of war against polytheists they must fight as one people, and neither Jews nor muslims were to make a separate peace, but peace was to be indivisible. In case of differences of opinion or disputes or controversy, the matter was to be referred to God through his messenger." (p. 123)

In fact, Jews were concerned about the advent of last prophet (pbuh) from their holy book, 'Torah'. And after his migration to Medina they recognized him as their desired prophet. So, here Muhammad (pbuh) diplomatically brought the two parties on a familiar point of revelation of God, so that 
they became bound to keep peace and order of Medina according to their own revelation.

vi.

In 628 A.D. along with 1400 followers Muhammad (pbuh) went out of Medina to perform Hajj, a pilgrimage to Kabah at Mecca. They put on the 'Ihram', pilgrim's grab, took their sacrificial animals, and got the only sword for each for self-defense according to the tradition of Arabs on this occasion (Sarwar, 1961, p.313). Hearing the news of their journey towards Mecca the 'Quraish' became extremely upset and made up their minds to prevent the Muslims from this holy pilgrimage. Lings (1983) wrote their sayings as mentioned, "By God, this shall not be," They said, "so long as there is a single eye amongst us with a glimmer of life left in it." (p. 248). Deciding this they took the necessary preparation for warfare. Joined by the surrounding tribes with a body of 200 horses, they sent a well equipped army under Khalid ibn Walid and Ikrama ibn Abu Jahl forward to the route of Medina (Khan, 1980). Meanwhile, prophet (pbuh) reached at 'Osfan', a second stage from Mecca and was informed the aggressive approach of Meccan. As he came out for peaceful pilgrimage, he decided to pass up the 'Quraish' army. Muslims were not afraid of battle and already they had given the evidences of their heroism in the previous battles over 'Quraish', yet they obeyed the order of prophet (pbuh) for the sake of peace. Avoiding the Meccan army on the high road, Muslim voyagers continued their journey through rugged pathways and reached at 'al-Hudaibiyya'. ${ }^{9}$ At this place prophet (pbuh) encamped and sent one of his companion to express their holy intention to Meccan.

Knowing the intention of prophet (pbuh), the 'Quraish' sent a team under Budail ibn Waraqa, a respected person, Husail and Urwa ibn Masud respectively to investigate the situation (Sarwar, 1961). From the part of Muslims, prophet (pbuh) sent his own son-in-law, Uthman ibn Affan to the idolaters for negotiation. But when the rumour of Uthman's murder reached to muslims, they pledge under a tree to take revenge of it saying, "I will fight unto death" (p. 318). Being apprehensive in this dreadful situation, 'Quraish' sent their final deputation under Sohail ibn Amr to negotiate with the Muslims and resolved the hectic problem. At last the treaty was drawn up between the two groups. Muhammad Ali (1972) writes down the main features of the truce as follow: i. "The Muslims shall this year return without performing the pilgrimage;

ii. Next year they may come but shall not stay at Mecca longer than three days;

iii. They shall not take with them any of the Muslims already living in Mecca, and, on the other hand, they shall not stand in the way of anyone from among themselves should he wish to remain behind at Mecca;

iv. Should any of the Meccans go over to Medina the Muslims shall stand him over to the Meccans; but if any of the Medinite Muslim should rejoin the Meccans, the latter shall not restore him to the Muslims;

v. The Arab tribes shall be at liberty to enter into alliance with whichever party they choose." (p. 147)

But the most noteworthy clause of the truce was the peace pact for ten years between the two parties resolving all types of conflicts. By this agreement the rivalry between the Meccans and Medinites came to an end for ever.

This truce was probably the greatest example of the sincerity and eagerness of prophet (pbuh) towards peace and conflict resolution. In this event we see more than one method to resolve the forthcoming dispute. Firstly, prophet (pbuh) performed the policy of avoidance to stay away from the warfare with the advanced army of 'Quraish'. Secondly, prophet (pbuh) showed an immense tolerance to regulate the ceasefire, as he kept patience over the cruelty of Meccans that they did with his messengers. Even, during the time of making treaty, Abu Jandal, a new Muslim, escaped from the custody of Meccan and begged shelter to the prophet (pbuh), he did not allow him to give shelter according to the condition of the treaty. His companions argued that at that very time the treaty was not written, so they were not bound to hand him over to Meccan. But, with the inconsiderate approach of Sohail, prophet (pbuh) made the decision in favour of 'Quraish' (Haykal, 1976, p.354). Finally, the method of negotiation was performed truly in the agreement. In the negotiation process prophet (pbuh) took all the proposals of 'Quraish' without any question just for resolving conflict. 
At the first sight, this treaty seemed as an insulting one for the Muslims as most of its clauses go against the Muslim's interest. And the companions of prophet (pbuh) also contradicted on some of its conditions, but Muhammad (pbuh) was determined to take the opportunity of peace at any cost. He welcomed the disgraceful agreement and proved his mastermind in resolving disputes. In fact, the treaty of 'al-Hudaibiyah' was an apparent victory for the Muslims. ${ }^{10}$ After that, Muslims got the opportunity to communicate with the other clans and to show their divine character and consequently a large number of people accepted Islam; Muhammad (pbuh) got the scope to spread the notion of Islam in international arena and to give an evidence for his greatness of all time. Quraish also acknowledged the political state of Medina and Islam as an equal power to them. Haykal (1976) writes,

"There was hence no reason to doubt that the Hudaybiyah Treaty was a victory for the Muslims. History has shown that this pact was the product of profound political wisdom and forsightedness and that it brought about consequences of great advantage to Islam and indeed to Arabia as a whole" (p.355).

\section{CONCLUSION}

Conflict, an inescapable part of our daily lives, fluctuates a lot for its various ingredients, and even with a slight change of place, time and circumstances its also reacts in a different mode. Its nature, feature and dimension are so diverse that by using only one method it is quite impossible to resolve it. Hence, the world thinkers draw out some process that should be undertaken for conflict settlement, which may need appropriate modification according to the condition of dispute. To establish peace and order in human society Islam also emphasizes on resolving conflicts. In this regard, Muhammad (pbuh), the prophet of Islam, dictated some unique process by his sayings and practices. Critical evaluation of those methods proves his mastermind and greatness of all ages. His observations on describing the nature of conflicts and on its different methods of solution for various disputes were really excellent. The current methods that we perform today seem to be the modified version of his practices, which can be proved by the examples of the above. In fact, in that ignorant period his thoughts gave a new look to the development of civilization, and even it may contribute a lot currently, especially to the conflict related to Muslim world.

\section{NOTES}

1 Allah says-"Indeed, the religion in the sight of Allah is Islam" (The holy Quran, 03:19).

2 Al Quran gives a perfect description on this event. For details please see the holy Quran, 02: 30-39; 07:11-25; 20: 115-127

3 (Pbuh)- Peace be upon him, an honorific sentence used after mentioning the name of Prophet Muhammad.

4 These are the general methods for conflict resolution. In brief, avoidance means that one adjusts itself not to cause any conflict; negotiation is a process of bargaining between the two sides for search of solution of a conflict; in mediation a third party acts as a middle person to suggest the terms of settlement of ending conflicts; Arbitration is a quasi-judicial mode of settlement among states in which the parties agree to one or more arbitrators to make a decision on a conflict; Adjudication means settlement by a judicial authority or tribunal; Coercion or force is the aggressive method of resolving a conflict (Rashid, 2005, pp.66-68).

5 Allah declares, "There has certainly been for you in the Messenger of Allah an excellent pattern for anyone whose hope is in Allah and the Last Day and [who] remembers Allah often" (The holy Quran, 33:21).

6 'Sirah' literally means biography, but as a term of Islamic history it means only the biography of prophet Muhammad (pbuh).

7 'Hijrah' or migration, terminologically used as the migration of prophet (pbuh) from his homeland Mecca to 'Yathrib', a 250 miles distance from the first and currently known as Medina, in 622 A.D.

8 Al- Aqaba is a place between 'Hira' and Mina near Mecca (Sarwar, 1961, p.167). The peoples of Median took their oath at this place and hence this pledge is named after this place.

9 'Al-Hudaibiyya' is an open tract of land below Mecca at the edge of the sacred territory (Lings, 1983, p. 248).

10 Allah says about the treaty, "Indeed, We have given you, [O Muhammad], a clear conquest" (The holy Quran, 48:01). 


\section{REFERENCES}

Ali, M.M. (1972). Muhammad the Prophet. Lahore: Ahmadiyyah Anjuman Isha`at Islam.

Athir, Ibn. (1965). Al Kamil fil Tarikh. Vol.ii, Bairut.

Barash, D.P. \& Webel, C.P. (2002). Peace and Conflict Studies, California: Sage Publications, Inc.

Fisher, R., Sources of Conflict and Methods of Conflict Resolution, http://www.aupeace.org/files/Fisher SourcesofConflictandMethodsofRe solution.pdf, accessed on 31.12.2010

Fisher, R.J. (1990). The social psychology of intergroup and international conflict resolution, New York: Springer-Verlag.

Guillaume, A. (1967). The Life of Muhammad. Lahore: Oxford University Press. Pakistan Branch.

Haykal, M.H. (1976). The life of Muhammad. Trans from $8^{\text {th }}$ edition by Ismail Ragi A. al Faruqi. USA: North American Trust Publication.

Husain, A. (1967). Prophet Muhammad and His Mission. Bombay: Asia Publishing House.

Katz, D. (1995). Nationalism and strategies of international conflict resolution. In H.C. Kelman (ed.), International behavior: A social psychological analysis. New York: Holt, Rinehart \& Inston.

Khan, M.A. (1983). Muhammd The Final Messenger. Lahore: Sh. Muhammad Ashraf.

Khan, M.Z. (1980). Muhammad: Seal of the Prophet. London: Routledge \& Kegan Paul Ltd.

Kriesberg, L. (1998). Constructive conflict: From escalation to resolution, Lanham, MD: Rowman \& Littlefield.

Lings, M. (1983). Muhammad his life based on the earliest sources. New Delhi: Vikas publishing House Pvt.Ltd. \& London: The Islamic Texts Society.

M`aluf, L. (1976). Al-Munjid. Arabic Dictionary. Beirut: Dar al Mashriq.

Rashid, H.U. (2005). An Introduction to Peace and Conflict Studies, Dhaka: The University Press Limited.

Sarwar, H.G. (1961). Muhammad The holy Prophet. Lahore: Sh. Muhammad Ashraf.

Weeks, D. (1992). The eight essential steps to Conflict Resolution, Los Angeles: Jeremy P. Tarcher, Inc. 